\title{
Crossborder Integration of Supply Chains: Problems and Digital Solution Concept
}

\author{
Djamilia F. Skripnuk \\ Peter the Great St.Petersburg \\ Polytechnic University \\ St. Petersburg, Russia \\ http://orcid.org/0000-0003-3773-9098
}

\author{
Vitaliy I. Cherenkov \\ Graduate School of Management \\ St. Petersburg State University \\ St. Petersburg, Russia \\ cherenkov@gsom.pu.ru
}

\author{
Nikolay I. Didenko \\ Peter the Great St.Petersburg \\ Polytechnic University \\ St. Petersburg, Russia \\ http://orcid.org/0000-0001-8540-7034
}

\begin{abstract}
The present paper is devoted to show and formalize logistics problems emerging on boarders between different logistics environments while crossing them by supply chain. The said problems consist of increasing logistics risk and transaction costs. It is shown that the solution of these problems constitutes a significant reserve for increasing the competitive advantage. The comparative-analytical approach is used to build a double-prism model of international logistics management. Crossborder supply chain integration is formalized using vector representation in a pair of $n$ dimensional spaces of logistic significant marketing variables. A prospective model of digital real-virtual cyberspace is presented as a hypothetical example of a fully digitalized logistics infrastructure. Didactic use of paper materials is explained.
\end{abstract}

Keywords - artificial intelligence, digitizing logistics infrastructure, logistics mix, marketing mix, operational risks, prismatic models, real-virtual cyberspace, swarm of drones

\section{INTRODUCTION}

Minimizing logistical risks and transaction costs are currently a substantial reserve for achieving a competitive advantage. Taking in an account that problems of crossborder integration of supply chains exist not only in international business but in domestic one for heterogeneous markets (as Russia) we have decided to use conceptual approaches developed for international logistics [1, Ch. 1]. As it was estimated [2, p. 11] average costs for international logistics were $25-35 \%$ of the sale price of goods [Long, 2004, p. 11]. Based on this, they estimate total annual world logistics costs as equil to \$5-6,5 trln. approximately. At the same time, they consider [3] the WTO Trade Facilitation Agreement (TFA) could reduce worldwide trade costs (where logistics costs make a substantial contribution) by between $10 \%$ and $18 \%$.

In Russia - a very large country with heterogeneous regional markets - the problem of logistics transaction costs and risks is particularly acute. Russian logistics costs in prices of final products could be $20-70 \%$.In comparison with other large countries (USA, Canada, and China), the share of logistical costs in the Russian GDP is significantly higher $(+49 \%,+46 \%,+19 \%$, respectively $)$. Not only the size of Russia determines the large logistics costs, but the following problems [4]: (1) difficult general economic situation and social tensions in all sectors of society; (2) long-term underestimation of the meaning of the sphere of product circulation in the economy and, therefore, logistics [N.B.! up to 1990s logistics discipline was not delivered in Russian economic universities]; (3) obsolete infrastructure (first of all, digital communications, roads and vehicles themselves) and its slow development; (4) substantial lag in the use of modern technologies (digital ones included) for the movement, transportation, storage and packaging of goods; (5) low level of development of production and technical and technological base of warehousing; (6) poor development of the industry for the production of modern packaging; (7) high degree of operational logistics risks (both due to the human factor, and due to IT soft/hard errors); (8) relatively low level of conceptualization of logistics and - last but not least - (9) lack of formalized (digitalized), clear, and detailed descriptions of logistic functions/operations, coordinated with other business processes of organization. Understanding an exceptionally wide range of all issues related to the problems of improving logistics, in this article we confined ourselves to the task of minimizing the logistics risks and transaction costs emerging during crossing the border between different logistic spaces (it doesn't matter within a country or between countries).

The results of a non-formal survey of Russian students and a number of managers have shown that the following proposition still holds true [5]: "The big problem is that so many do not actually understand what logistics is." Therefore, there are a few logistics concepts presented necessary to define one of digital applications to be used to match a pair of supply chain parts located in different logistics environments. Finally, there are many definitions of international logistics but all of the have a similar feature could be illustrated by the following [6]: "International logistics involves the management of these resources in a company's supply chain across at least one international border". This addition - concerning to the obvious fact of crossing at least one international border - to the classical convenient CSCMP general (non-international) definition of logistics can hardly internationalize the subject defined for the purpose of better understanding scope and sense of international logistics. On the opposite side of the trial to understand international logistics a descriptive approach takes place $[7 ; 8$, p. 51.]. These authors having passed through a number of business functions took place in international trade operations gave an obvious evidence that the canvas of international trade and - in more wider context - international business is well-reinforced by international logistics functions.

However, both of these approaches are far, in our opinion, from the conceptualization of international logistics, which we consider as a methodology for operationalizing the task of cross-border supply chain integration.

\section{CONCEPTUALIZING INTERNATIONAL LOGISTICS}

The history of marketing thought - in full conformity with the Gripstrud's subtitle of his conceptual article ("Time to regain lost territory?") [9] - confirms the genetic proximity between marketing and logistics. In particular, this is confirmed by the close relationship between marketing and logistics activities in marketing channels $[10 ; 11 ; 12 ; 13 ; 14]$. 
Sometimes they even said [15] about "natural inseparability" between marketing and logistics. Finally, logistics and marketing have the same DNA - an exchange considered as their initial and basic category. Beginning from the cult article by Richard Bagozzi [16], the statement concerning the core place and meaning of exchange for the marketing theory has been repeatedly confirmed [17].

Therefore, this genetic relationship between marketing and logistics could be considered as proved and we suppose the "marketing approach" [18] could be used for conceptualizing the subject of international logistics.

Note once again that "international logistics" is used here to represent a pair of different logistics environments only. It does not matter whether these logistics environments are in different countries or in one country. They should be more or less different for arising the problem of the crossborder integration of supply chain. The main conclusion is the possibility of applying a well-developed marketing theory for the case of conceptualizing logistics. As a result, we consider eligible the use of marketing concepts, models and approaches, such as "marketing mix", "marketing ecology" [19, Ch. 2], and "comparatively-analytical approach" [20].

By omitting a number of former intermediate evidences $[1$, Ch. 1], we give a definition for a logistics mix that plays an equally important role in supply chain integration as the marketing mix for connecting a seller with buyers or target market. International/domestic logistics mix is a set of logistics functions/operations (managed or controllable variables) that provides cross-border product movement in accordance with essential terms and conditions of sale contract (supported by transportation contract and corresponding payments) that should be adjusted to specifics of corresponding dimensions of logistics environment in the host (destination) country/region. Taking into account the fact that any logistic operations must be provided with relevant documents, we have proposed the notion codified logistics mix; namely [ibid]: a contract package and supporting documents/procedures that are necessary to realize legal, reliable and effective cross-border movements of complex logistics flows (product, financial, and information ones) to provide the integrity of corresponding crossborder supply chain. Finally, we present an object function of logistics management - integrating cross-border parts of supply chains provided decreasing logistics risks and transaction costs.

\section{PRISMATIC MODELS OF LOGISTICS MANAGEMENT AND REPRESENTATIONS OF THE TASK OF CROSSBORDER INTEGRATING SUPPLY CHAINS}

The main purpose of this section is to show the principle of cross-border supply chain integration and the multidimensionality of this task, which requires the adoption of digital technologies. To better understand the nature of the cross-border passage of logistic flows, we have used the analogy with the passage of a beam of white light (quasioptimal logistics mix A) through a glass prism (fig. 1).

The managed variables are presented in papers $[21 ; 22]$ like flexible tools for adjusting complex structured processes. Whereas one of common interpretations of $7 R$ is [23, p. 35]: "Ensuring the availability of the right product, in the right quantity and the right condition, at the right place, at the right time, for the right customer, at the right cost". It is easy to notice the following contradiction $-7 \mathrm{R}$ is a desired logistics result while logistics mix - as a "sibling" of marketing mix must be composed of managed variables that are considered as flexible tools serve for adjusting a quasioptimal logistics mix A (LMA) to conditions of logistics environment B or for converting the LMA to the LMB (fig. 2).

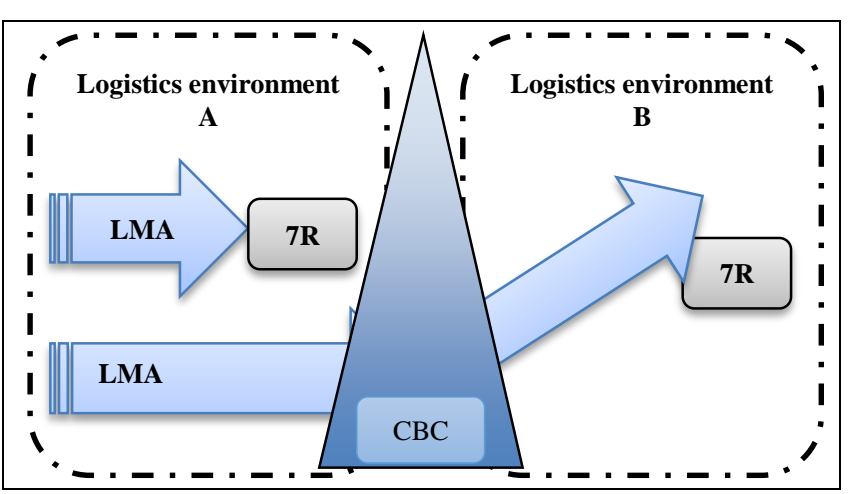

Fig. 1. A conceptual prismatic model of dissipation of logistics mix components while logistics flows are crossing the border between different logistics environments

\section{Legend:}

LMA - quasioptimal logistics mix for logistics environment A; CBD crossborder mismatching of logistics mix components; $7 \mathrm{R}$ - mnemonic representation of successful execution of a logistics task; $\mathrm{CBC}-$ crossborder conditions.

Source: designed by authors

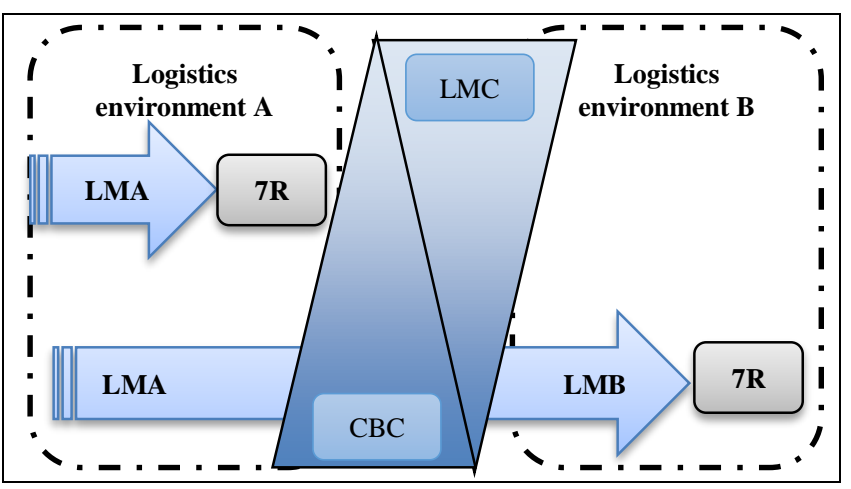

Fig. 2. A conceptual double prism model of logistics management, designed to show the principle of adapting logistics mix $\mathrm{A}$ to the conditions of the logistic environment $\mathrm{B}$

\section{Legend:}

LMA - quasioptimal logistics mix for logistics environment A; LMB quasioptimal logistics mix for logistics environment $\mathrm{B} ; 7 \mathrm{R}$ - mnemonic representation of successful execution of a logistics task; $\mathrm{CBC}$ -

crossborder conditions; LMC - logistics management corrections.

Source: designed by authors

Therefore, a controllable logistics mix could serve for crossborder integrating supply chains and consequently for minimizing logistics transaction costs and risks. However, we should make further additional notes concerning the nature of logistics risks. These prismatic models above could serve as didactic materials only to be used in economic universities for better understanding reasons of dissipation of logistics mix and considering ways how logistics managers could readjust this logistics mix to changed environment. However, real logistic variables (controllable as well as uncontrollable ones) should be considered herein to become closer to practice of 
adjusting logistics functions/operations to changed logistics environment. Consider two sources that systematize data of interest for cross-border supply chain integration - textbook $[8$, p. 51] and professional Logistics Performance Index (LPI) [24] created by analogy with KPI forms (N.B.! Russian Federation had $86^{\text {th }}$ aggregated LPI rank or $64.2 \%$ from the rank of the highest performer). Now, let's spend two imaginary experiments on the basis of two sources above.

Suppose that in region A the supplier has created a quasioptimal logistics mix A. According to data from [8, p. 51] logistics manager has to estimate following variables of logistics environment $\mathrm{B}$ and adjust accordingly the logistics mix A (table 1).

TABLE I. Some Measures For AdJusting Logistics Mix

\begin{tabular}{|l|l|}
\hline $\begin{array}{l}\text { Dissimilarities could be revealed } \\
\text { in logistics environment B }\end{array}$ & \multicolumn{1}{|c|}{$\begin{array}{c}\text { Possible changes/measures } \\
\text { necessary to do, concerning } \\
\text { logistics mix A }\end{array}$} \\
\hline $\begin{array}{l}\text { Sociocultural variables relevant to } \\
\text { logistic functions (including } \\
\text { cultural / language infrastructure } \\
\text { variables) }\end{array}$ & $\begin{array}{l}\text { - Studying new business culture } \\
\text { and modifying managers' } \\
\text { behavior. } \\
\text { - Translating contract documents. }\end{array}$ \\
\hline $\begin{array}{l}\text { Different vehicles, carriers, forms } \\
\text { of transport documents, } \\
\text { unexpected changing distances } \\
\text { and transit time }\end{array}$ & $\begin{array}{l}\text { Prior study of these features and } \\
\text { making adjustments }\end{array}$ \\
\hline $\begin{array}{l}\text { Legal status and business practice } \\
\text { of intermediaries included in the } \\
\text { next part of supply chain. }\end{array}$ & $\begin{array}{l}\text { Prior study of previous } \\
\text { experiences (if any) and making } \\
\text { adjustments (personal contacts } \\
\text { included) }\end{array}$ \\
\hline $\begin{array}{l}\text { Unknown logistics risks and } \\
\text { dangers }\end{array}$ & $\begin{array}{l}\text { Prior identifying logistics risks and } \\
\text { dangers and preparing tools of the } \\
\text { relevant risk management. }\end{array}$ \\
\hline $\begin{array}{l}\text { Reliable and valid insurers and } \\
\text { insurance terms }\end{array}$ & $\begin{array}{l}\text { Prior control and buyer's } \\
\text { (consignee's) acceptance in } \\
\text { writing }\end{array}$ \\
\hline $\begin{array}{l}\text { Validity and accept of selected } \\
\text { conditions and means of } \\
\text { international payments }\end{array}$ & $\begin{array}{l}\text { Prior control and buyer's } \\
\text { (consignee's) acceptance in } \\
\text { writing }\end{array}$ \\
\hline $\begin{array}{l}\text { Terms of delivery (currently } \\
\text { Incoterms }{ }^{\circledR} \text { 2010); }\end{array}$ & $\begin{array}{l}\text { Careful selection and buyer's } \\
\text { (consignee's) acceptance in } \\
\text { writing }\end{array}$ \\
\hline $\begin{array}{l}\text { Specific customs clearance and } \\
\text { related procedures (if any) }\end{array}$ & $\begin{array}{l}\text { Applying to customs broker } \\
\text { (obligatory for the first experience) }\end{array}$ \\
\hline $\begin{array}{l}\text { Logistics Security for danger } \\
\text { cargoes }\end{array}$ & $\begin{array}{l}\text { Following relevant instructions } \\
\text { (special marking and signaling } \\
\text { included) }\end{array}$ \\
\hline documentation & $\begin{array}{l}\text { Careful paperwork and/or applying } \\
\text { to corresponding consulting } \\
\text { organization or buyer (consignee) }\end{array}$ \\
\hline Source: companging
\end{tabular}

Source: compiled and adapted to the aim of the present paper by authors on the basis of [8, p. 51] and personal in-depth interview with a set of logistics managers

Now we reproduce six indicators of The World Bank's Logistics Performance Index (LPI) [24] with a nature of logistics risk given in round brackets in italics: (1) the efficiency of customs and border management clearance (risk of delays); (2) the quality of trade- and transport-related infrastructure (risk of cargo loss/damage; risk of delays; destination errors); (3) the ease of arranging competitively priced international shipments (competitiveness risk); (4) the competence and quality of logistics services (operational risks from overcapacity, congestion, backlogs and bottlenecking as well as resulting from disruption by labor unions, strikes, work stoppages); (5) the ability to track and trace consignments (risk of cargo loss/damage; risk of delays; destination errors); and (6) the frequency with which shipments reach consignees within the scheduled or expected delivery time (risk of delays; destination errors).
Comparing data in table 1 . with the set of LPI indicators above they could note that number and nature of logistics functions/operation with built-in risks is substantially increasing while cargo (goods) cross national/regional border and some of variables of logistics environment are drastically changed. Besides, there are a lot of hidden variables in a logistics mix. For example, the Incoterms ${ }^{\circledR} 2010$ is mentioned in the table 1 as a logistics variable to be considered from the viewpoint of terms of delivery. However, on the one hand, there are 11 terms in the set of Incoterms ${ }^{\circledR} 2010$ (apart from variations). On the other hand, every of these terms has $10 \mathrm{~A}$ and $10 \mathrm{~B}$ descriptions. We suppose that this example is sufficient to show the exceptional multidimensionality and complexity of the practical adjusting a logistics mix to conditions of the new / modified logistic environment. To finalize this section a vector representation of a crossborder integration of supply chain is presented (fig. 3) that could be considered as a first conceptual step toward digital integrating logistics infrastructure.

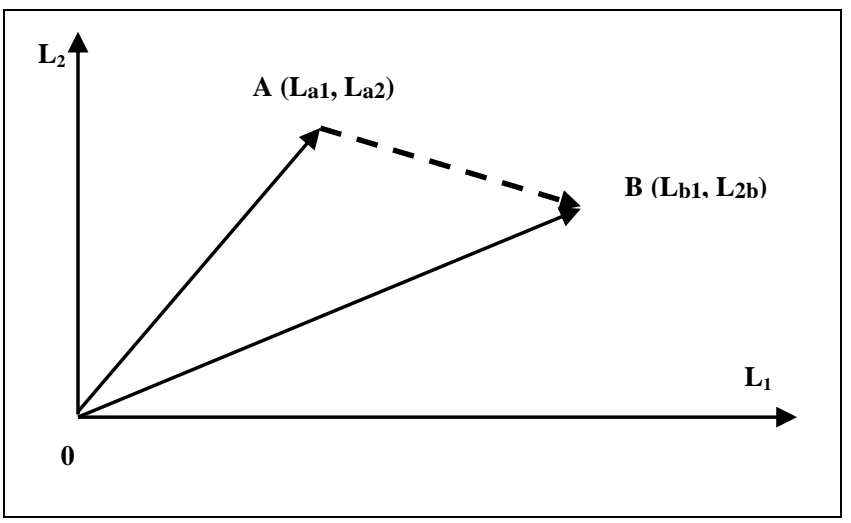

Fig. 3. A simplified two-dimensional vector representation of crossborder supply chain integration by adapting logistics mix A to logistics

\section{Legend:} environment B

$\mathrm{OA}$ - logistics mix A; OB - logistics mix B; $\mathrm{AB}$ - representation of an adapting program to be done to integrate a supply chain while crossing the border between logistics environments A and B.

Source: designed by authors

Let us turn to the n-dimensional logistics environment $\mathrm{A}$ and present the corresponding quasioptimal logistics mix OA in matrix form:

$$
\left[\begin{array}{ccccc}
\text {OA}_{11} & \text { OA12 }_{12} & \text { OA13 }_{13} & \cdots & \text { OA1n } \\
\text { OA21 }_{21} & \text { OA22 }_{21} & \text { OA23 }_{23} & \cdots & \text { OA2n }_{2 n} \\
\text { OA31 }_{31} & \text { OA32 } & \text { OA33 } & \cdots & \text { OA3n } \\
\cdots & \cdots & \cdots & \cdots & \cdots \\
\text { OAm1 } & \text { OAm2 }_{m} & \text { OAm3 } & \cdots & \text { OAmn }
\end{array}\right]
$$

Repeat the same operation to represent the quasioptimal logistics mix OB in the logistics environment $\mathrm{B}$ and get:

$\left[\begin{array}{ccccc}\mathrm{OB}_{11} & \mathrm{OB}_{12} & \mathrm{OB}_{13} & \cdots & \mathrm{OB}_{1 n} \\ \mathrm{OB} 21 & \mathrm{OB} 22 & \mathrm{OB} 23 & \cdots & \mathrm{OB} 2 n \\ \mathrm{OB} 31 & \mathrm{OB} 32 & \mathrm{OB} 33 & \cdots & \mathrm{OB} 3 n \\ \cdots & \cdots & \cdots & \cdots & \cdots \\ \mathrm{OB} 11 & \mathrm{OB} 2 & \mathrm{OB} 33 & \cdots & \mathrm{OB} m\end{array}\right]$

In accordance with the vector representation in Fig. 2, it is necessary to identify the difference between the coordinates 
of the points $\mathrm{A}$ (vector $\mathrm{OA}$ ) and $\mathrm{B}$ (vector $\mathrm{OB}$ ) in corresponding $\mathrm{n}$-dimensional logistic environment. This difference will show the necessary changes in logistics functions / operations that should be made with the help of logistics managementin (fig. 2), in order to adapt logistics mix A to dissimilar dimensions of logistics environment $\mathrm{B}$ (OB $\mathrm{OA}=\mathrm{AB}$ ). Of course, some of elements in the matrix $\mathrm{AB}$ below will be zero; that is, no changes in the logistics mix A will be required. A number of other minor elements in the same matrix could be neglected.

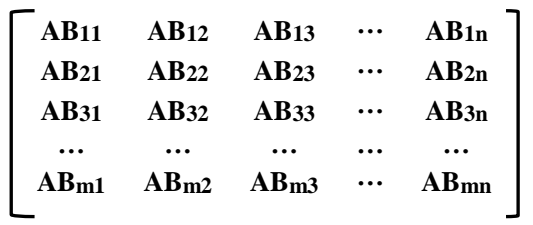

Before proceeding to the analytical description of the prospective model of the Arctic digital real-virtual cyberspace, it is necessary to make a comment on the holistic approach to the logistics infrastructure. This approach, as it is mentioned in a previous section, consider an expanded understanding of logistics as science and art of managing different duplex flows (material, informational, financial, and human). Metaphorically, it looks like a combination of nerve signals, as well as blood, lymph, food and water flows necessary for the normal functioning of a living organism. And all this is done under the control of the brain, in the role of which - in the case of a digitized logistics infrastructure a digital infrastructure space works (fig. 4).

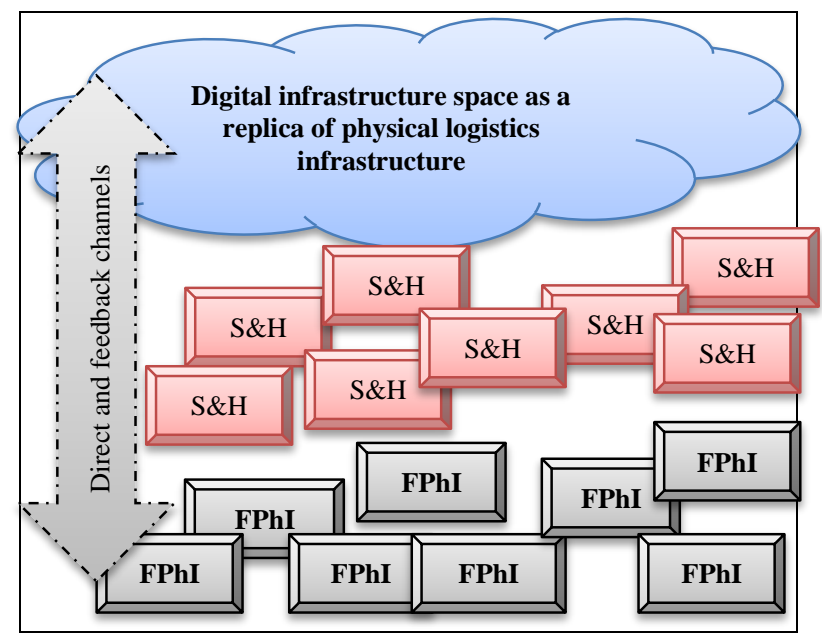

Fig. 4. Conceptual model of three-part digitized logistics infrastructure

\section{Legend:}

S\&H - software and hardware for the functioning of the logistics infrastructure; FPhI - facilities of physical infrastructure (aerospace systems included)

Source: designed by the authors

The digital economy as a whole - from the viewpoint of logistics - is presented as a complex IT platform providing innovative, balanced and effective development and using a digitized logistical infrastructure. Digital logistics manages not only information collection, storage and processing in the systems ensuring the "right" movement of material items carried on various types of transportation means, but also systems of trade exchange, production, and all other key business processes in supply chains. Besides, digitized logistics infrastructure is valuable from the viewpoint of sustainable development where logistics activities are not limited to providing logistics services only. Now much attention is paid to innovations in the light of sustainable logistics that are defined as [25]: "The implementation of a for-the-firm new, or significantly improved, service, process, or organization in a logistics activity, that contributes to a more environmentally and/or socially sustainable development". Therefore, contemporary digitized logistics infrastructure has to serve three classes of tasks: economic, environmental and social ones. Therefore, the number of variables characterizing logistics environments $(m, n)$ has been drastically increased and early "trial and error" logistics methods based on check-lists and personal experience of logistics managers are unacceptable now. Digitizing logistics infrastructure permits to use advanced innovative digital technologies from rather simple ones (e.g., digitalized barcode equipment, different mobile applications, digitalized toll plazas [26]) to much more sophisticated (e.g., Big Data [27] and other advanced technologies of Fourth Industrial Revolution [28]).

\section{Prospective Model Of ARctic Digital ReaL- VIRTUAL CYBERSPACE AS AN EXAMPLE OF DigITALIZED LOGISTICS INFRASTRUCTURE}

First of all it is necessary to explain why the Arctic Zone of Russian Federation (AZRF) has been chosen as an example of prospective digitizing its logistics infrastructure. Note that we use herein the term "logistics infrastructure" due to the fact of a broader interpretation of logistics as a complex set of real (physical) and virtual (digital) facilities supporting controlled duplex movements of logistics flows of different nature (material, financial, informational and even human). Factually, logistics infrastructure is an important universal network to connect the AZRF with other part of Russia and foreign countries. The AZRF's industries create about $12,5 \%$ (by other estimations up to 15,0\%) of Russian GDP while its population is about 2,2\% of the population of Russian Federation. Then, Russia has by far the largest Arctic coastline, more than 17,500 kilometers long. So, the AZRF is very important from military viewpoints. To understand better the state of the Art in AZRF's logistics infrastructure outputs of corresponding SWOT-analysis are presented in Table 2.

Strengths. Taking into account space-and-industry fragmentariness of the AZRF, its huge space and the remoteness of corresponding fragments from federal and regional centers of governance the government politics and direct participation (through government organizations and public-private partnership) in developing the AZRF's logistics infrastructure is absolutely necessary. The main and indisputable argument for this statement is the progress of Soviet Arctic politics and its decadence during first decades of Russia. The North Sea Route (NSR) inherited from the Soviet period and intensively modernized nowadays should be considered not only as a backbone of a Russian SiberianArctic logistics mega-infrastructure (fig. 5) but as a backbone structure for implementation numerous projects digitizing and integrating partial logistics infrastructures of the AZRF. As it was announced in the very beginning of 2019 Russian government has decided to increase drastically the Arctic investments (digitalizing issues included). According to the complex plan "Realization of the mineral and logistical potential of the Arctic"118 projects are announced (March 
2019) and a total budget for them should be equal to $\$ 178$ bln., (https://www.vestifinance.ru/articles/116165).

Weaknesses. For implementing the state programme "Socioeconomic Development of the Arctic Zone of the Russian Federation" (AZRF Program), the Ministry of Economic Development of Russian Federation and Ministry of Industry and Trade of Russian Federation have been assigned by Russian government in 2014 as program performer executive and program co-performer, respectively [29]. Besides, ten federal ministries, services, agencies, and organizations have been assigned as the participants of the AZRF Program. It is not so difficult to assume a further ramification of governing structures on municipal-regional levels. The only means of overcoming expected information losses and distortions in the said governing structures could be presented by a hypothetical holistic computerized information network for the AZRF.
TABLE II. SWOT-ANALYSIS MATRIX, CONCERNING STATE OF THE ART AND PROSPECTIVE OF DEVELOPMENT OF LOGISTICS INFRASTRUCTURE OF THE ARCTIC ZONE OF RUSSIAN FEDERATION

\begin{tabular}{|c|c|}
\hline STRENGTHS & WEAKNESSES \\
\hline $\begin{array}{l}\text { Assignment a variety of projects } \\
\text { commonly known as "Digital } \\
\text { Arctic" }\end{array}$ & $\begin{array}{l}\text { Uneven distribution of resources } \\
\text { and production and difficult } \\
\text { logistics }\end{array}$ \\
\hline $\begin{array}{l}\text { hievements of domestic } \\
\text { cialists }\end{array}$ & $\begin{array}{l}\text { Weakened and not-fully restored } \\
\text { state Arctic politics }\end{array}$ \\
\hline $\begin{array}{l}\text { High quality human capital } \\
\text { involved }\end{array}$ & $\begin{array}{l}\text { Raw material exporting model of } \\
\text { development }\end{array}$ \\
\hline $\begin{array}{l}\text { Favorable geographical position } \\
\text { as a West-East-West logistics } \\
\text { bridge }\end{array}$ & $\begin{array}{l}\text { High vulnerability to severe } \\
\text { weather changes and natural } \\
\text { disasters }\end{array}$ \\
\hline $\begin{array}{l}\text { consequences of climate } \\
\text { es }\end{array}$ & $\begin{array}{l}\text { of coordination } \\
\text { different Arctic actors }\end{array}$ \\
\hline $\begin{array}{l}\text { istrative, } \\
\text { and financial } \\
\text { uplementing RF } \\
\text { olitics }\end{array}$ & $\begin{array}{l}\text { and regulators } \\
\text { Substantial risk for private / } \\
\text { foreign investors } \\
\text { Weak development of existing }\end{array}$ \\
\hline ivate / & $\begin{array}{l}\text { fragmented extremely logistics } \\
\text { infrastructure } \\
\text { Lack of holistic computerized }\end{array}$ \\
\hline ctic-focused & ork for the \\
\hline $\begin{array}{l}\text { The } \mathrm{p} \\
\text { con } \\
\text { AZ }\end{array}$ & scientific analysis and \\
\hline $\begin{array}{r}\text { AZ } \\
\text { Partic }\end{array}$ & $\begin{array}{l}\text { Slow implem } \\
\text { oriented in }\end{array}$ \\
\hline $\begin{array}{l}\text { Emergency (ME) and Army } \\
\text { forces } \\
\text { Theoretical and practical herita } \\
\text { of Russian Arctic studies }\end{array}$ & $\begin{array}{l}\text { iation of research } \\
\text { izations }\end{array}$ \\
\hline & \\
\hline $\begin{array}{r}\text { Expecte } \\
\text { the } A\end{array}$ & $1-$ \\
\hline $\begin{array}{r}\text { Increa } \\
\text { natu }\end{array}$ & es of climate \\
\hline $\begin{array}{l}\text { Expected formation an } \\
\text { institutionalization of } \\
\text { "supporting zones" }\end{array}$ & $\begin{array}{l}\text { nal } \\
\text { ion and overall } \\
\text { ance }\end{array}$ \\
\hline and selective labor & ompetition for \\
\hline Significant improvement in & administrative contradictions \\
\hline technologies & onnel as a result of \\
\hline $\begin{array}{r}\text { Digi } \\
\text { ma }\end{array}$ & $\begin{array}{l}\text { ing state politics } \\
\text { rolatility of hydrocarbo }\end{array}$ \\
\hline $\begin{array}{l}\text { Developing Arctic UAV fleet } \\
\text { system in the frame of AeroNet } \\
\text { (Action Plan of National } \\
\text { Technological Initiative) }\end{array}$ & $\begin{array}{l}\text { prices* } \\
\text { State budget restrictions due to an } \\
\text { arms race } \\
\text { Further anti-Russia sanctions }\end{array}$ \\
\hline
\end{tabular}

Legend:

*as consequences of a worldwide crisis;

NSR - North Sea Route;

Source: [30] revised and replenished by the authors from the viewpoint of logistics infrastructure meaning for Russian Federation and problems of its development.

It sounds strange, but the mainly right statement of the AZRF Strategy - "After the partial digital regional areas are created, the integration of them must be completed on the level of the AZRF as a whole. Therefore, a new phenomenon of an "e-Arctic" zone based on coastal settlements interconnected by telecommunications along the NSR should emerge." [30] - is practically not detailed in the AZRF Program. Probably, a lot of work is to be done for developing the relevant subprograms (new ones are on the way now). Finally, our socalled "fast and cheap" research carried out as a reviewing a substantial number of Russian articles and conference proceedings relevant to items of Russian Arctic has revealed dozens appropriate works but comparing its lists of references 
forces to doubt that a good networking between authors (organizations) exist. Taking into account an interdisciplinary nature of the problem of creating a digital logistics infrastructure in the AZRF, it seems that a role of coordinator for a corresponding research could be assigned to polytechnic universities of Russia. Such a decision could help to use better and multiply achievements of Russian Arctic studies and related to IT innovations. Finally, there is a conflict of interest between different Russian AZRF's stakeholders.

Threats. Analyzing the content of box "Threats" (table 2) can conclude that any limitations of the Arctic program state budget items jeopardize implementation of the logistics infrastructure digitalization program. Indeed, on the one hand, any negative financial causal relationships of the "Threats $\Rightarrow$ Strengths" category create vulnerabilities for almost all of components necessary for effective and fast digitizing the AZRF: (1) closing or freezing the projects of class "Digital Arctic"; (2) slowing development of Arctic-focused hard and soft; (3) decreasing the investment attractiveness for private / foreign investors; (4) facilities and equipment for monitoring logistics flows of different nature, and (5) downsizing theoretical and applied research concerning issues of AZRF's digital logistics infrastructure. On the other hand, the negative financial casual relationships of the "Threats $\Rightarrow$ Strengths" category exacerbate problems of digitizing the AZRF's logistics infrastructure/ namely: (1) further deterioration of an underdeveloped computerized information network intended to serve as a framework for building a prospective digital AZRF's logistics infrastructure; (2) freezing development of AZRF's transport logistics infrastructure (including digital monitoring); (3) increasing perceived risks for private / foreign investors; and (4) further slowing development and implementation of special Arctic digital technological and organizational innovations concerning AZRF's logistics infrastructure.

Opportunities. Despite the importance of institutional [31] and organizational [32] factors for crossborder integrating supply chains where the said digitized logistics infrastructure should be its universal and flexible framework we are forced to concentrate our attention on technological innovations. According to our expert judgment based on reviewing relevant academic literature and official sources the following main technological pillars for sustainable development in the AZRF need to be highlighted: (1) digital technologies coupled with aerospace, wireless and ground means of telecommunications [33]; and (2) air logistics mainly supported by unmanned aerial systems (UASs) - remotely piloted aircrafts (RPAs) or unmanned aerial vehicles (UAVs) or "drones" - also coordinated and guided with the help of aerospace communication means $[34 ; 35]$. Both of these technological digitized pillars are closely related to each other and are part of the digitized logistics infrastructure (fig. 5).

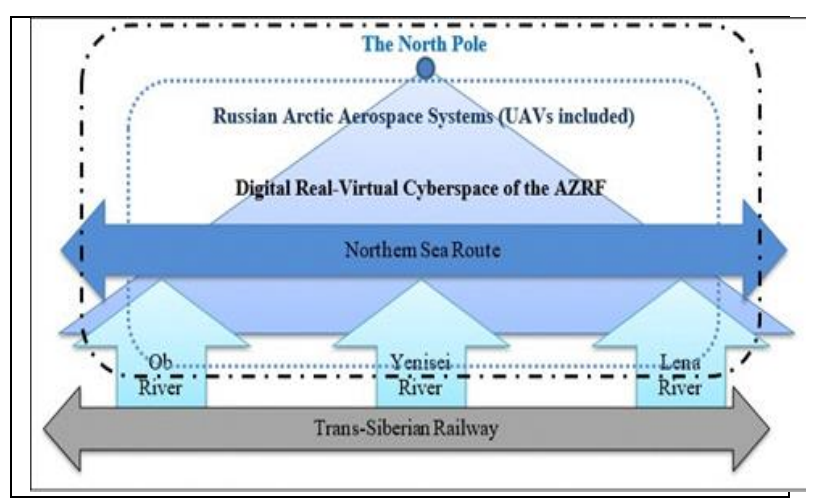

Fig. 5. Conceptual model of a prospective digitized logistics infrastructure of the AZRF supported by Arctic Aerospace Systems (land and sea facilities are not shown)

Source: [36] with changes made by the authors

Geographical peculiarities, ecological vulnerability, notso-well-arranged logistics connections with the rest of Russia, and so-called "administrative remoteness" and relatively low feedback with federal governance centers as well as a poor transparency of business/social processes in the AZRF exacerbate problems of integrating supply chains in this zone. The XXX International Scientific Conference MMET-30 was focused on items of management systems based on supercomputers and high speed means of communication. Using such powerful computerized systems should create a digitized logistics infrastructure where a "digital replica" of AZRF's "supporting zones" should be represented. Next step should be a virtual representation of the AZRF's logistics infrastructure as a whole in a "cyberspace" that could be considered as a tool of logistics management.

Naturally, according to the principle of specialization applied to collecting, processing and storing relevant information (data) concerning development of the AZRF they should arrange and direct information flows according to following domains (subspaces) that are categorized but not limited to: (1) major "smart cities" (factually, centers of "supporting zones"); (2) tracking mobile filed camps necessary for different Arctic research; (3) monitoring inbound and outbound logistics on territories where oil/gas and other mineral resources extraction takes place; (4) surveillance on recreational areas (extremal tourism groups included); (5) surveillance of fishing grounds and gathering seafood (anti-poachers actions); (6) organization and control of shipping in the Northern Sea Route; (7) providing logistics services in favor of defense and protection against natural disasters. While digitizing the AZRF they see a huge work to be done on the way to creating digital logistics infrastructure having networks of partial relationships between different actors and institutions, processes and procedures, etc.

The digital real-virtual cyberspace of the AZRF has to be considered not only as charged with logistics functions but as a complex and flexible tool of federal/regional governance. An appeal to such a tool of indicative planning does not contradict property relations in a capitalist economy. On the contrary, indicative planning methods supported by digital technologies should attenuate inevitable impacts of operational risks [37]. However, we estimate operational logistics risks as very important menace for successful 
digitizing logistics infrastructure in the AZRF (and also in other Russian regions). Indeed, operational risk is the risk of loss resulting from inadequate or failed processes or systems, human factors or external events.. Operational risk events in logistics infrastructure can occur due to: (1) logistics managers are not well-qualified (in the field of modern IT, especially); (2) logistics functions / operations that should support crossborder integrating are flawed; (3) soft / hard systems that should facilitate the activity are broken; and (4) unexpected external event occur in home / host logistics environment that disrupts an integrity of supply chain.

However, according to general provisions concerning a nature of software architectures it is expected to formulate the hypothesis according to which they could get to more effective crossborder integration based on coordinated set of specialized information systems, means of computer modelling and artificial intellect algorithms. An impact of feedback channels (fig. 4) has been noted at various levels of control with the help of digital technologies. For example [38], on microeconomic level, including digital technologies on workplaces created a new distinct culture, impacting the previous work culture and the general work experience. However, on macroeconomic (or mesoeconomic) level, there is a much more perspective way of creating a set of partial real-virtual logistics infrastructures (RVLIs) that, in our case, could be interpreted as the conjunction of digital replica of AZRF's supporting zones with different logistics flows have to cross border between dissimilar fragments of logistics environment in the AZRF. Under so harsh and volatile Arctic conditions, the RVLIs should be exclusively attractive because they are characterized [39] as self-star (self-*) systems (i.e., self- $*$ = self-awareness, self-configuration, selfmanagement, self-organization, self-diagnosis, selfcorrection and self-repair). Therefore, at this level, impacts from the virtual replica of the AZRF on logistics infrastructures inside its real (today, mainly probabilistic) part should be evident too.

The logistics infrastructure soft and hard components (supercomputers, network servers, monitoring and communication satellites, etc.) are to be arranged in such a way that Arctic logistics flows (goods, services, information, finance and personal) move with minimal risks and transaction costs. Therefore, speaking about Arctic logistics infrastructures in the AZRF, we mean not only cargo/passenger transportation logistics but also logistic activities related to intangible operations, namely [40]: (1) forwarding services; (2) customs (if any), trade and financial activities; (3) service and consultancy services; (4) information flows supplying logistics information systems. The holistic logistics system in the AZRF should be (in the future) an integrated network of navigable seaways (the NSR junctions with Great Siberian Rivers - fig. 5), ports, terminals and offshore structures interconnected with main railroads, airports, roadways, pipelines, and river transport. The typical Arctic problem of AZRF's logistics infrastructure is the clear impossibility of the year-round operation of many branches of the said infrastructure. Seeking to provide innovative logistics solutions for Arctic logistics it should be noted that the extended areas of permafrost and the considerable length of supply chains place air logistics outside of any competition with other logistics means. Besides, using an air logistics simplify the problem of crossborder integration of supply chain due to "free air mode". Traditionally the Arctic was explored and served - in addition to maritime and terrestrial facilities - by aircrafts and helicopters adjusted for peculiarities of Arctic environments (using polar airships was stopped in the beginning of the last century due to wellknown catastrophes). However, the state of the Art with the polar civil aviation in contemporary Russia is considered as a very poor one [41]. Therefore, the air logistics dilemma - to revitalize previous Arctic aviation projects or leapfrog traditional Arctic aviation solutions toward an intensive development and implementation such innovative ones as a set of drone fleets (UASs) coordinated and/or guided with the help of aerospace communication means (fig. 5) - has to be resolved in favor of the latter. In addition, the most advanced drone fleets incorporated into digitized logistics infrastructure serve as so called distributed processing systems (DPS) [42]. Therefore, unlike traditional air logistics such drone fleets (swarms) fulfill the principles of DPS - in which drones are the nodes, and the system fully manages by itself using its internal algorithms and mechanisms. Factually, they are talking about AI applications in modern drone logistics. It is clearly defined [43] that UAVs are better suited for "dull, dirty, or dangerous" missions or D-missions than manned aircraft because a man is (or should be) the limiting factor in performing certain airborne roles in the said risky "D-missions". Harsh environment of Arctic puts people and technics (equipment) in a situation similar to military action and UASs having AI components will be the best replacement for manned aircrafts. Thus, the digitizing the logistics infrastructure takes place both within the logistics means and in its control environment.

\section{CONCLUSION}

The present mainly theoretical research allows a number of conclusions. First of all, logistics present a huge reserve for minimizing logistics risks and transaction costs. Secondly, crossborder integration of supply chain demands application of comparatively analytical approach to analyzing neighboring logistics environments and revealing their dissimilarities. Vector and matrix representation of the task of crossborder integrating supply chains give a way for computer added decision making. Third, number of such dissimilarities and rate of their changes could be so substantial that only digital technologies can handle them. In the fourth, at the time of Fourth Industrial Revolution the digitizing logistics infrastructure has no alternative but has a lot of options: from mobile devices in hands of logistics managers up to AI on board of transportation means and other logistics facilities. In the fifth, the beacon of further digitizing logistics infrastructure is seen for us as a holistic auto-adjustable realvirtual cyberspace having AI capacities which main feature is minimizing logistics transaction costs and risks due to crossborder integrating supply chains. At sixth, an example of issues of creating logistics infrastructure on the basis of a heterogeneous mesoeconomic system (such as Arctic Zone of Russian Federation) has shown that digitizing logistics infrastructures has to have a total nature relating to all logistics flows (material, informational, financial and human ones). Finally, issues of logistics are not-so-well conceptualized in Russia ad further research should be done by interdisciplinary 
teams. This fact can have a negative effect on the training of logistics managers and IT specialists involved in digitizing logistics infrastructures. As a result, logistics operational risks could be increased and the proper way of digitizing logistics infrastructure could be slowed down. The authors hope that the conceptualization and formalization of the tasks of crossborder integration of supply chains as well as corresponding graphic materials presented herein materials could be used in the teaching process.

\section{REFERENCES}

[1] V. Cherenkov, Prolegomena of international logistics, Publishing house of St. Petersburg State University, St. Petersburg, Russia, 2016, 488 pages. (in Russian)

[2] D. Long, International logistics: global supply chain management, Springer US, New York, p. 11, 2004

[3] Why trade facilitation matters in today's global economy, Trade Facilitation, On-line, URL: http://www.oecd.org/trade/topics/tradefacilitation/ (Retrieved at May, 2019)

[4] General theoretical foundations of logistics On-line, URL: https://refdb.ru/look/2140472-pall.html/ (Retrieved at May, 2019)

[5] Ilin, I. V., Izotov, A. V., Shirokova, S. V., Rostova, O. V., \& Levina, A. I. (2017). Method of decision making support for it market analysis. Paper presented at the Proceedings of 2017 20th IEEE International Conference on Soft Computing and Measurements, SCM 2017, 812814.

[6] What Is International Logistics? - Definition, Lesson \& Quiz Education Portal, 2015, On-line, URL: http://educationportal.com/academy/lesson/what-is-international-logistics-definitionlesson-quiz.html\#lesson (Retrieved at May, 2019)

[7] T. Niine and O. Koppel, "Logistics Management in the Era of Supply Chain Management - A Gap in Academic Literature", Scientific Papers (www.scientificpapers.org), Journal of Business Management and Applied Economics, vol. III, Issue 3, May 2014, pp. 1-23.

[8] P.A. David and R.D. Stewart, International Logistics: The Management of International Trade Operations, Cengage Learning, Maison, USA, 2010

[9] A.I. Klimin, D.V. Tikhonov, A.M. Efimov, "Evaluation of the effectiveness of marketing communications in Russian business using the example of St. Petersburg enterprises," Proceedings of the 30th International Business Information Management Association Conference, IBIMA 2017 - Vision 2020: Sustainable Economic development, Innovation Management, and Global Growth. Spain, vol. 1, pp. 1465-1482.

[10] R. Bartels, The history of marketing thought. 2d ed. Columbus, $\mathrm{OH}$ : Grid, 1976

[11] E. Sweeney, "From the management of distribution to the management of supply chains:the evolution of SCM", Logistics Solutions, 2006, pp. 11-14.

[12] I. Ilin and A. Grigoreva, "How stakeholders make decision about changes in enterprise architecture. Cases in private business and public organization", MATEC Web of Conferences, 2017, 106,08010

[13] P.D. Larson and A. Halldorsson, "Logistics versus Supply Chain Management: An International Survey", International Journal of Logistics: Research and Applications, 2004, vol. 7, No. 1, pp. 17-31

[14] J. Lynch and L. Whicker, "Do logistics and marketing understand each other? An empirical investigation of the interface activities between logistics and marketing", International Journal of Logistics Research and Applications, 2008, vol.11, Iss. 3, pp. 167-178.

[15] Ilin, I.V., Iliashenko, O.Y., Klimin, A.I., Makov, K.M. Big data processing in Russian transport industry (2018) Proceedings of the 31st International Business Information Management Association Conference, IBIMA 2018, pp. 1967-1971.

[16] R. P. Bagozzi, "Marketing as exchange", Journal of Marketing, 1975, vol. 39, no. 4, pp. 32-39.

[17] A. Alvarez-Milán, R. Felix, P. A. Rauschnabel and C. Hinsch, "Strategic customer engagement marketing: A decision making framework", Journal of Business Research, 2018, vol. 92, pp. 61-70

[18] V. Filipović, V. Milićević and N. Zarkić-Joksimović, "Customer Oriented Marketing Concept and Strategic Enterprise Development in
Balkan Economies", FACTA UNIVERSITATIS, Series: Economics and Organization, 2000, vol. 1, no 8, pp. 9-16

[19] S. Majaro, International Marketing. A Strategic Approach to World Markets, Routledge, London, New York. 1993

[20] L. Moutinho and Ch. Chien, "Problems in Marketing: Applying Key Concepts and Techniques", SAGE Publications Ltd., Los Angeles, etc. 2008 pp. $274-277$

[21] N.I. Didenko, D.F. Skripnuk, K.N. Kikkas, G. Romashkin and S.V. Kulik, "The analysis of convergence - Divergence in the development of innovative and technological processes in the countries of the Arctic Council", International Conference on Information Networking, 2018, pp. 626-631, (ICOIN, Chiang Mai, Thailand, 2018-January 2018), DOI: 10.1109/ICOIN.2018.8343194

[22] N.I. Didenko, D.F. Skripnuk, O.V. Mirolyubova and E. Samylovskaya, "System of econometric equations of the world market of natural gas", International Conference on Information Networking, 2018, pp. 217222, (ICOIN, Chiang Mai, Thailand, 2018-January 2018), DOI: 10.1109/ICOIN.2018.8343113

[23] J.J. Coyle, E.J. Bardi and C.J.J. Langley, The Management of Business Logistics, 5th ed. St.Paul, MN: West Publishing Co., 1992, p. 35.

[24] J-F. Arvis, L. Ojala, Ch. Wiederer, B. Shepherd, A. Raj, K. Dairabayeva and T. Kiiski, Connecting to Compete 2018. Trade logistics in the global economy: The Logistics Performance Index and Its Indicators. The International Bank for Reconstruction and Development/The World Bank. Washington, DC, 2018

[25] D. J. Flint, E. Larsson, B. Gammelgaard and J. T. Mentzer, "Logistics innovation: A customer value-oriented social process", Journal of Business Logistics, 2005, vol. 26, No. 1, pp. 113-147.

[26] A Levina, A.I., Dubgorn, A.S., Iliashenko, O.Y. Internet of things within the service architecture of intelligent transport systems (2018) Proceedings - 2017 European Conference on Electrical Engineering and Computer Science, EECS 2017, pp. 351-355.

[27] Y. Wang, L. Feng, H. Chang and M. Wu, "Research on the Impact of Big Data on Logistics", 2017 MATEC Web of Conferences, DOI: 10.1051/matecconf/201710002015

[28] J. Buguin, R. Dobbs, P. Bisson and A. Marrs, Disruptive Technologies: Advances That Will Transform Life, Business, and the Global Economy; McKinsey Global Institute: San Francisco, CA, USA, 2013

[29] The state programme "Socioeconomic Development of the Arctic Zone of the Russian Federation" On-line URL: http://static.government.ru/media/files/GGu3GTtv8bvV8gZxSEAS1R 7XmzloK6ar.pdf (Retrived at 02.02.2019) (in Russian)

[30] Russian Strategy of the Development of the Arctic Zone and the Provision of National Security until 2020 (2013) (in Russian) On-line URL: http://textarchive.ru/c-1065721-pall.html (Retrived at 02.09.2018)

[31] S. De Dasgupta and Y. Cian, "Institutions and Environment: Existing Evidence and Future Directions", Nota di Lavoro no 41, Fondazione Eni Enrico Mattei Milano Italia, 2016, 35 pages

[32] L. Laurian and J. Crawford, "Organizational Factors of Environmental Sustainability Implementation: An Empirical Analysis of US Cities and Counties", Journal of Environmental Policy \& Planning, 2016, vol. 18 Iss 4 pp. $482-506$

[33] A. Raspotnik and S. Steinicke, "The Arctic's Economic Future is Digital", The Arctic Institute, 2017, On-line URL: https://www.thearcticinstitute.org/arctic-economic-future-digital/ (Retrived at 30.02.2019)

[34] H. Shakhatreh, A. Sawalmeh, A. Al-Fuqaha, Z. Dou, E. Almaita, I. Khalil, N.S. Othman, A. Khreishah and M. Guizani, "Unmanned Aerial Vehicles: A Survey on Civil Applications and Key Research Challenges", 2018, On-line URL: https://arxiv.org/pdf/1805.00881.pdf (Retrived at 30.02.2019)

[35] Big Potential for Drones in the Arctic, UAS Vision. 2016, On-line URL: https://www.uasvision.com/2016/06/22/big-potential-fordrones-in-the-arctic/ (Retrived at 30.08.2018)

[36] N.I. Didenko and V.I. Cherenkov, "Economic and geopolitical aspects of developing the northern sea route", In Proceedings of the IOP Conference Series: Earth and Environmental Science, St. Petersburg, Russian Federation, 18-19 April 2018, vol. 180, 012012. doi:10.1088/1755-1315/180/1/012012, 2018, 180(1) 
[37] Operational Risk Supporting Documentation to the New Basel Capital Accord, Bank for International Settlements, Basel Committee on Banking Supervision, Basel, Switzerland, 2002.

[38] J. Buchanan, B. Kelley and A. Hatch, "Digital workplace and culture: How digital technologies are changing the workforce and how enterprises can adapt and evolve", Deloitte Development LLC, 2016, On-line

URL:

https://www2.deloitte.com/content/dam/Deloitte/us/Documents/huma n-capital/us-cons-digital-workplace-and-culture.pdf (Retrived at 30.02.2019)

[39] Maydanova, S., Ilin, I. Problems of the preliminary customs informing system and the introduction of the Single Window at the sea check points of the Russian Federation (2018) MATEC Web of Conferences, 239, 04004

[40] J. Kolár, "Logistics activities in relation to tangible and intangible operations", Scientific journal on transport and logistics, 2010, no 2(1), pp. $29-34$
[41] A. Fedotovskikh, "The Polar Aviation of Russia", Pro-Arctic, 2014, On-line URL: http://pro-arctic.ru/16/05/2014/technology/8454 (Retrived at 12.02.2019) (in Russian)

[42] G. Chmaj and H. Selvaraj, "Distributed Processing Applications for UAV/drones: A Survey", International Conference on Systems Engineering, At: Las Vegas, vol. 1089, 2014

[43] Unmanned aircraft systems roadmap 2005-2030, 2005, On-line URL: https://fas.org/irp/program/collect/uav_roadmap2005.pdf (Retrived at 28.02.2019) 